\title{
The role of SAGA in the transcription and export of mRNA
}

\author{
E.N. Nabirochkina @, M.M. Kurshakova, S.G. Georgieva, D.V. Kopytova \\ Institute of Gene Biology, RAS, Moscow, Russia \\ هe-mail: elenan5@rambler.ru
}

\begin{abstract}
SAGA/TFTC, which is a histone acetyltransferase complex, plays an important role in the regulation of transcription. We have identified that the metazoan TFTC/STAGA complexes had histone $\mathrm{H} 2 \mathrm{~A}$ and $\mathrm{H} 2 \mathrm{~B}$ deubiquitinase activity that is carried out by a DUBm (deubiquitination module). We studied the DUBm of SAGA in Drosophila melanogaster and identified Drosophila homologs of yeast DUBm components. Two subunits of DUBm (Sus1/ENY2 and Sgf11) were shown to have functions separate from DUBm function. Thus, Sus1/ENY2 was shown to be present in several different complexes. Sgf11 was found to be associated with the cap-binding complex (CBC) and recruited onto growing messenger ribonucleic acid (mRNA). Also, we have shown that Sgf11 interacted with the TREX-2/AMEX mRNA export complex and was essential for mRNA export from the nucleus. Immunostaining of the polytene chromosomes of Drosophila larvae revealed that Sgf11 is present at the sites of localization of snRNA genes. It was also found in immunostaining experiments that $\mathrm{dPbp} 45$, the subunit of the PBP complex, the key player in the snRNA transcription process, is associated not only with the snRNA gene localization sites, but with other sites of active transcription by Polll. We also revealed that Sgf11 was present at many active transcription sites in interbands and puffs on polytene chromosomes, Sgf11 was localized at all Brf1 (the component of the RNA polymerase III basal transcription complex) sites. We concluded that SAGA coactivated transcription of both the Polll and Pollll-dependent snRNA genes.

Key words: transcription; SAGA; DUB module; AMEX; Sgf11; ENY2; snRNA genes; Polll-dependent transcription; Pollll-dependent transcription.
\end{abstract}

For citation: Nabirochkina E.N., Kurshakova M.M., Georgieva S.G., Kopytova D.V. The role of SAGA in the transcription and export of mRNA. Vavilovskii Zhurnal Genetiki i Selektsii =Vavilov Journal of Genetics and Breeding. 2019;23(2): 174-179. DOI 10.18699/VJ19.478

\section{Роль SAGA комплекса в транскрипции и экспорте мРНК}

\author{
Е.Н. Набирочкина $\otimes$, М.М. Куршакова, С.Г. Георгиева, А.В. Копытова
}

Институт биологии гена Российской академии наук, Москва, Россия

هe-mail: elenan5@rambler.ru

\begin{abstract}
Гистон-ацетил трансферазный комплекс SAGA/TFTC играет важную роль в регуляции транскрипции. Нами было обнаружено, что TFTC/STAGA комплексы метазоа деубиквитинируют гистоны H2Aи H2B. Был определен модуль TFTC/STAGA комплекса, который обладает деубиквитиназной активностью (DUBm). Мы исследовали DUBm у Drosophila melanogaster и идентифицировали гомологи - компоненты DUBm дрожжей. Нами было показано, что белок Sgf11, один из компонентов DUBm у Drosophila, обладает другой, отличной от DUBm функцией. Белок Sgf11 ассоциирован с CAP-содержащим комплексом и рекрутируется на растущую матричную рибонуклеиновую кислоту (мРНК). Кроме того, мы обнаружили, что Sgf11 взаимодействует с TREX-2/AMEX комплексом экспорта мРНК, и этот белок необходим для экспорта мРНК из ядра. Другие две субъединицы DUBm Drosophila также обладают функциями, отличными от функции DUBm. Так, выявлено, что Sus1/ENY2 присутствует в нескольких различных комплексах. Эксперименты по иммуноокрашиванию политенных хромосом личинок Drosophila показали, что Sgf11 присутствует на всех сайтах локализации генов, кодирующих мяРНК, и что так же, как hSNAPC1, dPbp45, субъединица РBP комплекса, играющая ключевую роль в транскрипции мяРНК, присутствует не только в сайтах генов мяРНК, но и в других сайтах активной транскрипции, осуществляемой РНКполимеразой II (PollI). Мы провели колокализацию на политенных хромосомах белков Sgf1 1 и Brf1 (компонента комплекса РНК-полимеразы III) и обнаружили, что Sgf11 находится во многих сайтах активной транскрипции и присутствует в тех же сайтах, что Brf1. Таким образом, мы показали, что SAGA коактивирует транскрипцию как PНК-полимеразы II-зависимых, так и РНК-полимеразы III-зависимых генов малых ядерных РНК.

Ключевые слова: транскрипция; SAGA; DUB модуль; AMEX; Sgf11; ENY2; гены мяPHK; Роlll-зависимая транскрипция; PollII-зависимая транскрипция.
\end{abstract}

\section{Introduction}

A large number of coactivator complexes are organized into transcription systems to provide accurate and precise functioning of the RNA polymerase II (RNAP II) machine. Coactivators are multisubunits complexes that are recruited to chromatin to promote transcription initiation by direct interaction with general transcription factors (GTFs) or RNAPII. They also may act indirectly through modification of chromatin structure (Li et al., 2007).

The yeast SAGA histone acetyltransferase (HAT) complex and its Drosophila and human homologs STAGA (the SPT3/ TAF9/GCN5 acetyltransferase complex)/TFTC (the TBP-free 
TAF complex) are multisubunits complexes that facilitate access of GTFs to DNA through histone acetylation mediated by the catalytic activity of the GCN5 subunit (Martinez, 2002). Human homologs of most SAGA subunits have been identified in TFTC/STAGA; biochemical and functional characterization demonstrated that the described human complexes are almost identical (hereafter called TFTC/STAGA) (Wu et al., 2004; Nagy, Tora, 2007).

The new components of the yeast SAGA complex were identified in biochemical studies bringing in additional functions to the complex (Powell et al., 2004; Rodriguez-Navarro et al., 2004). Ubp8 is a ubiquitin-specific protease, which has a histone $\mathrm{H} 2 \mathrm{~B}$ ubiquitin protease activity in this complex and is incorporated into SAGA through interaction with Sgf11 (Lee et al., 2005). H2B ubiquitination plays an important role in gene silencing and in activation of specific genes. Both ubiquitination and deubiquitination of $\mathrm{H} 2 \mathrm{~B}$ are required for optimal gene activation (Henry et al., 2003; Daniel et al., 2004). In higher eukaryotes, histone H2A is also monoubiquitinated (H2Aub1). It is interesting that Sus1, which is the component of both SAGA and the Sac3-Thp1 mRNA export complex in yeast (Rodriguez-Navarro et al., 2004), interacts with Sgf11 and Ubp8 and regulates the deubiquitination activity of the complex (Kohler et al., 2006).

\section{TFTC/STAGA complex has a modular organization that links the deubiquitination function to HAT and DUBm}

We analyzed a highly purified human TFTC fraction by MS-MS mass spectrometry and identified three additional subunits of TFTC/STAGA (USP22, ATXN7L3 and ENY2). Human USP22 is the homolog of yeast Ubp8; human ATXN7L3 is the homolog of the yeast Sgf11 protein; and ENY2, a 101 amino acid protein, is homologous to yeast Sus1. We showed that the ubiquitin protease USP22 together with ATXN7L3 and ENY2 forms a deubiquitination module (DUBm). Also, we revealed that two different TFTC/STAGA subunits, TAF5L and ATXN7, interact with this module and may mediate its association with TFTC/STAGA (Zhao et al., 2008).

Then, we studied the DUBm of SAGA in Drosophila melanogaster. Drosophila homologs of yeast DUBm components have been identified. Nonstop, Sgf11 and ENY2 are homologous to yeast Ubp8, Sgf11 and Sus1, respectively, and were shown to be components of SAGA (Weake et al., 2008). Drosophila Nonstop and Sgf11 have a role in H2B deubiquitination (Weake et al., 2008). A putative Drosophila ortholog of yeast Sgf73 was also identified (Weake et al., 2009). However, the existence of an integrated DUBm in Drosophila has not been shown. We demonstrated that endogenous Drosophila ENY2, Sgf11 and Nonstop form an integrated DUBm associated with SAGA.

First, we raised antibodies against Sgf11 and Nonstop (subunits of DUBm) in rabbits, antibodies against the ENY2 component were described previously (Georgieva et al., 2001) and performed immunoprecipitation experiments. Antibodies against Sgf11 co-precipitated Nonstop from the nuclear extract of Drosophila embryos. Moreover, antibodies against either Sgf11 or Nonstop co-immunoprecipitated not only ENY2, but also the Gen5 subunit of SAGA (Fig. 1). Thus, we confirmed the existence of a SAGA-associated DUBm in Drosophila melanogaster. It should be noted that a certain amount of Sgf11 remained in the extract after treatment with antibodies against Nonstop or ENY2. Hence Sgf11 also may perform their function in a complex other than SAGA DUBm.

Our previous data showed that the SAGA complex participates in the transcription of the Drosophila heat-shock protein $70(h s p 70)$ gene during heat shock (Lebedeva et al., 2005). So, we analyzed the function of Sgf11 in gene expression using the $h s p 70$ gene model. The antibodies against Sgfl1 strongly stained $h s p 70$ puffs on Drosophila larval polytene chromosomes after heat shock, indicating that Sgf11 participates in the transcription of $h s p 70$. Then we used a chromatin immunoprecipitation (ChIP) assay to study the occupancy of the $h s p 70$ promoter by Sgfl1 and other DUBm subunits before and after gene activation. Sgf11 was detected on the hsp 70 promoter, its association with the promoter turned out to be RNA-dependent unlike that of ENY2 or Nonstop.

Earlier we demonstrated an interaction between E(y)2/ENY2 and the nuclear pore complex (NPC) and showed that SAGA/TFTC also contacts the NPC at the

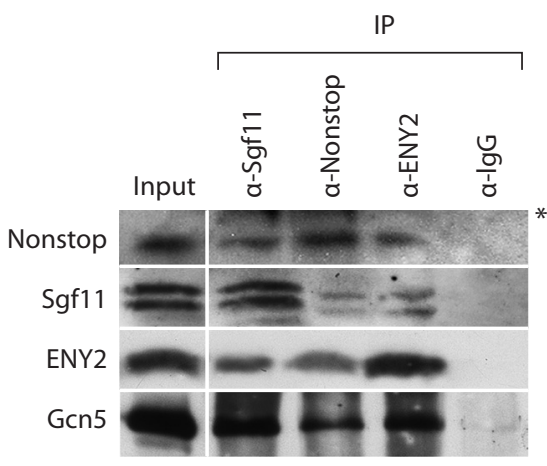

Fig. 1. Sgf11 interacts with DUBm subunits and the Gcn5 component of SAGA in nuclear extract from Drosophila embryos in co-immunoprecipitation experiments (IP).

Antibodies against Sgf11, Nonstop, ENY2 and Gcn5 or preimmune serum (PI) were used. Bands indicated with an asterisk correspond to antibodies (adapted from (Gurskiy et al., 2012)).

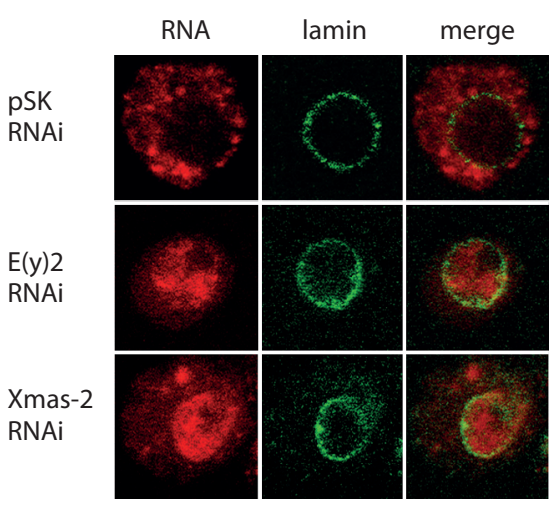

Fig. 2. $E(y) 2$ and Xmas-2 are required for mRNA export from the nucleus. $E(y) 2$ and Xmas-2 are required for poly $(\mathrm{A})+\mathrm{RNAexport}$ from the nucleus.

RNAi was performed using either dsRNA corresponding to a fragment of pSK II vector as a control or the $\mathrm{E}(\mathrm{y}) 2$ or the Xmas-2 cDNAs. RNA FISH was carried out using a Cy3-labelled oligo(dT) probe to identify poly (A) + RNA. Nuclear envelope is stained with lamin. Representative examples of cells are shown (magnification, $\times 1000$ ) (adapted from (Kurshakova et al., 2007)).

nuclear periphery. E(y)2/ENY2 also forms a complex with the X-linked male sterile 2 (Xmas-2) protein to regulate mRNA export from nucleus to cytoplasm both in normal conditions and after heat shock. This complex was named AMEX/TREX2 (Fig. 2). Importantly, $\mathrm{E}(\mathrm{y}) 2 / \mathrm{ENY} 2$ and Xmas-2 knockdown decreased the contact between the $h s p 70$ gene loci and the nuclear envelope before and after activation and interfered with transcription.

Based on these data, we performed RNA-IP experiments and found that 
$a$

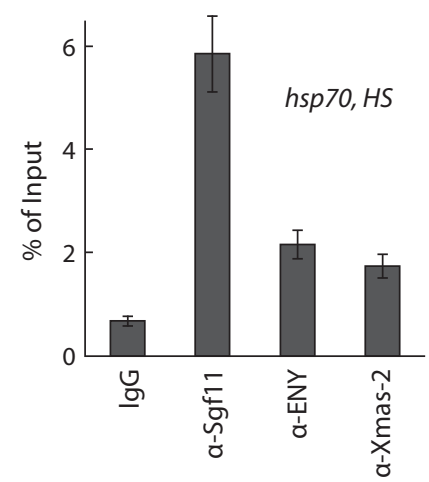

b

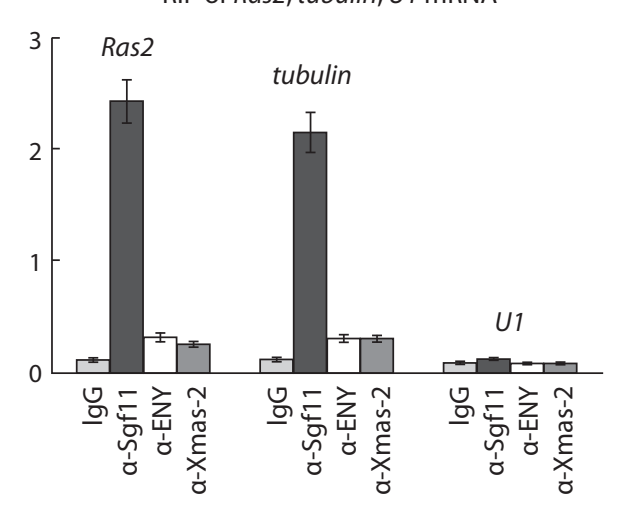

Fig. 3. Sgf11 is associated with mRNAs of several genes.

$a$ - RIP experiments with $h s p 70$ mRNA after heat shock were performed using antibodies against Sgf11 or components of the mRNA-interacting AMEX complex (ENY2, Xmas-2); nonimmune IgG was used as control. The results are shown as a percentage of input; $b$ - Sgf11 binds to mRNAs of ras and tubulin genes under normal conditions. The U1 snRNA was used as a control. Antibodies used in RIP experiments were the same as in Fig. 3, a. The results are shown as a percentage of input (adapted from (Gurskiy et al., 2012)).
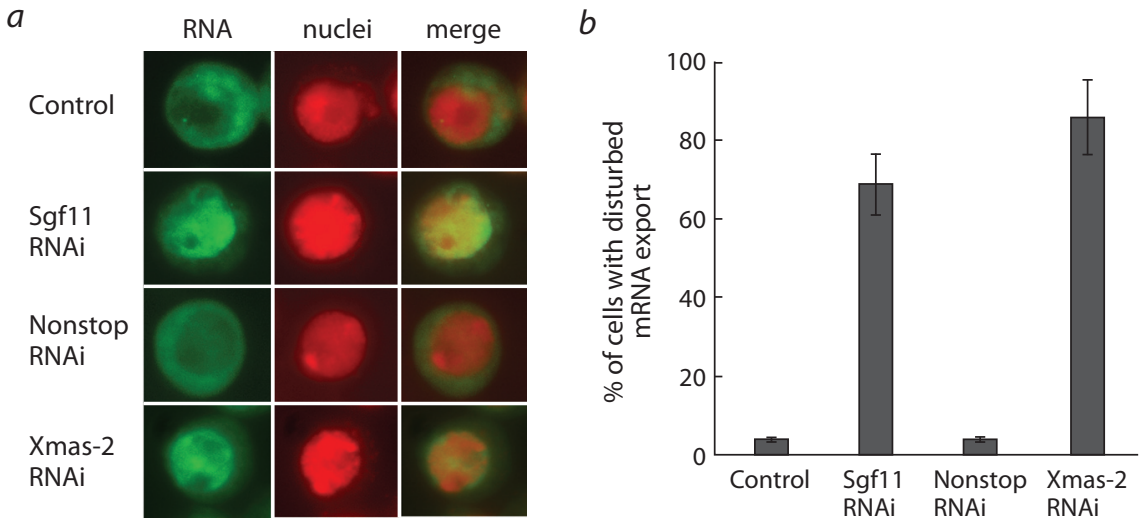

Fig. 4. RNAi knockdown of Sgf11 interferes with general mRNA export.

$a-$ RNAi knockdown of Sgf11, but not Nonstop, interferes with general mRNA export. Cells were treated with GFP dsRNA (control) or dsRNA corresponding to Sgf11 and Nonstop. Xmas-2 RNAi knockdown was performed as a positive control. Representative examples of the distribution of mRNA (green staining) and cell nuclei (red staining) and the corresponding merged images are shown for control cells and cells after Sgf11 or Nonstop knockdown (magnification, $\times 1000$ ). RNA FISH was carried out using a Cy3-labeled oligo(dT) probe to identify poly(A)+ RNA. The nuclei were stained blue with DAPI. The images were recolored in Photoshop for better visualization.

$b$ - quantitative presentation of the results of experiments shown in Fig. 4, a. Bars show the percentage of cells with disturbed $h s p 70$ mRNA nuclear export (about 200 cells per RNAi experiment were examined) (adapted from (Gurskiy et al., 2012)).

$a$

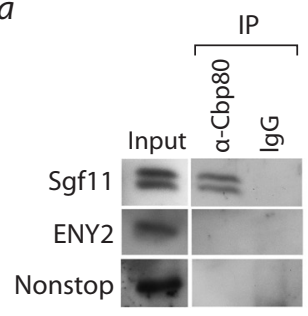

$b$

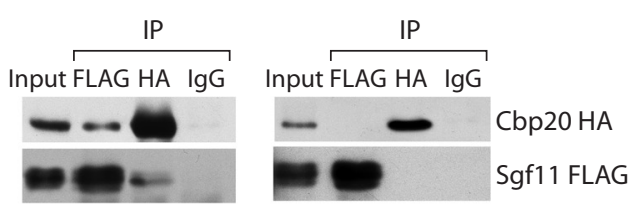

Fig. 5. Sgf11 is associated with Cbp80 in a separate complex.

$a$ - co-immunoprecipitation experiments with nuclear extract of Drosophila embryos reveal no interactions between Cbp80 and ENY2 or Nonstop DUBm components.

$b$ - recombinant Sgf11 interact with Cbp80 but not with Cbp20. FLAG-tagged Sgf11 was co-expressed with HA-tagged Cbp80 or HA-tagged Cbp20 in transiently transfected S2 cells. Immunoprecipitation was performed with anti-FLAG or anti-HA antibodies or with IgG. The Western blot was stained with anti-FLAG of anti-HA antibodies. About $10 \%$ of the input and $50 \%$ of the precipitate were loaded onto the gel (adapted from (Gurskiy et al., 2012)).

Sgf11 was associated with $h s p 70$ mRNA and with mRNAs of two other genes (Ras2 and tubulin). Antibodies against Sgf11 immunoprecipitated mRNA even more efficiently than did antibodies against Xmas-2 or ENY2 (Fig. 3). We have also found that Sgf11 interacts with the AMEX/TREX2 complex and similarly to Xmas-2 and ENY2 colocalizes with NPC. We demonstrated that knockdown of Sgf11 disrupted mRNA export of both $h s p 70$ mRNA and the total mRNA (Fig. 4). Therefore, Sgf11 interaction with AMEX/TREX-2 may play an important role in general mRNA export (Gurskiy et al., 2012).

\section{Sgf11 is present in several complexes in the Drosophila embryo nuclear extract and is associated with $\mathrm{Cbp} 80$ independently of the DUBm}

Then, we purified Sgf11-containing complexes from the embryonic nuclear extract and revealed that Sgf11 was associated with the $\mathrm{Cbp} 80$ subunit of the Cap-Binding Complex (CBC). This result was confirmed in co-immunoprecipitation experiments (Fig. 5). Moreover, our data on co-expression of recombinant Sgf11 and Cbp80 in Drosophila $\mathrm{S} 2$ cell culture demonstrated that Sgf11 directly interacts with Cbp80, and $\mathrm{Cbp} 80$ was necessary for Sgf11 recruitment; this interaction was independent of the other subunit of the CBC complex, Cbp20. Thus, Sgf11 functions independently of the DUBm in mRNA export. In fact, the other two subunits of the DUBm were also shown to have functions separate from the DUBm function. Thus, Sus1/ENY2 was shown to be present in several different complexes (Kurshakova et al., 2007; Kopytova et al., 2010). Human ataxin 7 , the homolog of the yeast Sgf73 subunit of the DUBm, was found in the cytoplasm and is involved in the regulation of cytoskeleton dynamics (Nakamura et al., 2012). Taken together, our data provide evidence that although Drosophila Sgf11 is an integral component of the SAGA DUBm, it also forms a complex with $\mathrm{Cbp} 80$ and associates with nascent mRNA. It interacts with the AMEX/ TREX-2 mRNA export complex and is involved in competent mRNP translocation to the cytoplasm. 


\section{SAGA is present at snRNA genes and interacts with Pbp45}

Mapping the binding sites for Sgf11 component of the SAGA complex on the polytene chromosomes of Drosophila larvae by immunostaining revealed that Sgf11 is present at the sites of localization of snRNA genes (Gurskiy et al., 2012). To verify this result, we performed double immunostaining of polytene chromosomes from the salivary glands of Drosophila using antibodies against Sgf11 and Pbp45, the subunit of the PBP complex, the key player in the snRNA transcription process. It was found that Pbp45 can be found not only at the snRNA loci but also at other actively transcribed sites (in puffs and interbands). Similar data had previously been obtained by the whole genome sequencing of hSNAPC1, the human Pbp45 homolog (Baillat et al., 2012). Our findings are the first indication that similar to hSNAPC1, dPbp45 is associated in addition to the snRNA gene localization sites, with other sites of active transcription by PolII.

Sgf11 and Pbp45 colocalized at many actively transcribed genes on polytene chromosomes, including those sites where $U 1-U 6$ snRNA genes are located. To confirm that the SAGA complex is indeed present at the promoters of the snRNA genes, we performed ChIP with antibodies against the components of SAGA (Sgf11, ENY2 and Gcn5) and Pbp45. All tested proteins were detected at the promoter regions of snRNA genes: at promoters of the genes transcribed by RNA polymerase II (snRNA U1 and snRNA U2) and at promoters of the U6 snRNA genes which are transcribed by RNA polymerase III.

To determine whether the subunits in the SAGA complex physically interact with the snRNA gene transcription apparatus, we co-immunoprecipitated the components of SAGA modules: the HAT module (Gen5 and Ada2b factors), the DUB module (Sgf11, ENY2, and Nonstop) and TRRAP, with the antibodies against the Pbp45 protein from the nuclear extract of the Drosophila S2 cells. Results obtained showed that protein components of both the HAT and DUB modules interact with Pbp45, and thus, with the PBP complex. Therefore, SAGA proteins are not only present at the promoter regions of snRNA genes, but they also interact with the snRNA transcription machinery. Moreover, SAGA participates in snRNA gene transcription guided by both PolII and PolIII. $a$

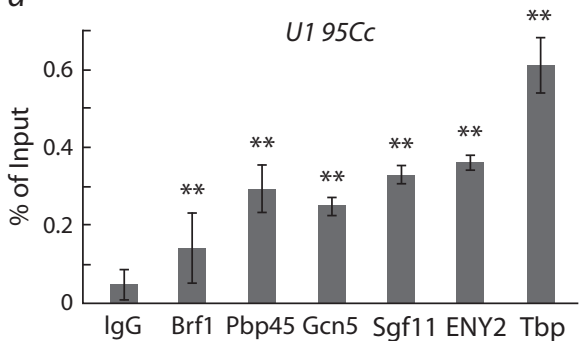

$b$

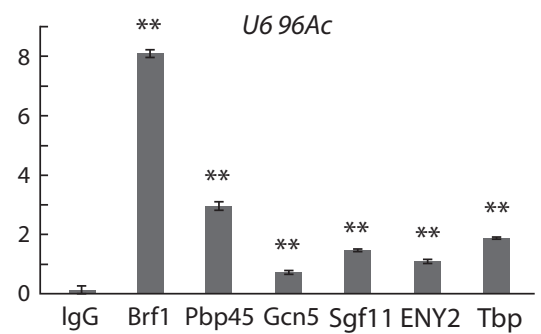

$C$

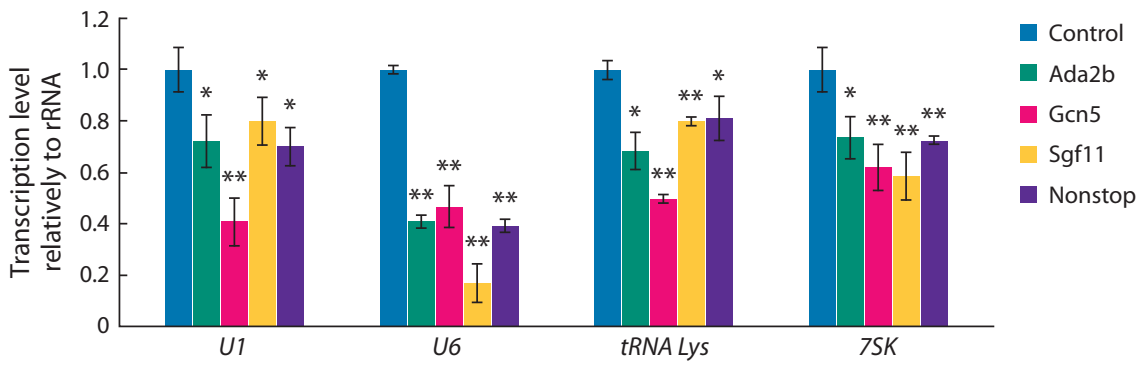

Fig 6. The participation of the SAGA complex in snRNA transcription.

( $a$ and $b$ ) - occupation of the U1 and U6 promoters (U1 95Cc, U6 96Ac) by Brf1, Pbp45, Gcn5, Sgf11, ENY2, and TBP in Drosophila pupat. The protein level was measured by ChIP. The results of ChIP are provided as a percentage of input.

$c$ - effects of decrease of Ada2b, Gcn5, Sgf11, and Nonstop transcription levels in mutant strains on the level of transcription of $U 1, U 6, t R N A$ Lys and $7 S K$ genes. TM6B, Tb[1]/+ strain was used as a control. The transcription levels were normalized on 28S rRNA. $t$ - tests have been performed to compare the means $\left({ }^{*} p<0.05 ;{ }^{* *} p<0.01\right)$ (adapted from (Popova et al., 2018)).
To detect SAGA at the RNA polymerase III-transcribed genes, we analyzed colocalization of Sgf11 and Brf1 (the component of the RNA polymerase III basal transcription complex) on polytene chromosomes. In contrast to Sgf11, which is present at many active transcription sites in interbands and puffs, Brf1 was found in a relatively low number of sites of the PolIII-transcribed genes. However, the immunostaining experiments revealed that Sgf11 was present at all Brfl sites. In particular, they colocalize at the loci corresponding to U6 and tRNA genes, as well as other RNA polymerase III target genes.

Recently, a ChIP-seq analysis of Drosophila embryos has shown that Ada2b, Nonstop, and Sgf11 occupied promoter regions of snRNA genes (Li et al., 2017). Our results obtained for Drosophila support these data and we have demonstrated that SAGA participates in the transcription of snRNAs. We have also shown that the SAGA complex participates in the transcription of other PolIII target genes: the U6 snRNA genes.

Chromatin immunoprecipitation using antibodies against the components of the SAGA complex and Brfl confirmed that SAGA is present not only at the promoters of individual U6 snRNA genes, but also at the promoters of other genes (RNase MRP and tRNA Lys) transcribed by RNA polymerase III (Fig. 6, $a-c$ ). Additionally, we have demonstrated that the protein components of both the HAT module and the DUB module interact with Brf1. All the tested SAGA subunits interacted with Brfl in the nuclear extract. Therefore, the SAGA complex is present at the promoters of the RNA polymerase III-transcribed genes and interacts with the RNA polymerase III transcription factors.

\section{The effect of mutations in the genes encoding SAGA complex subunits on snRNA transcription}

Next, we have checked whether mutations of subunits of the SAGA complex could change snRNA gene transcription in flies. The effect of mutations in genes encoding SAGA components on snRNA transcription in Drosophila showed that it is indeed the case. First, we showed that all studied factors were present on the promoters of snRNA genes in flies (chromatin was prepared from Droso- 

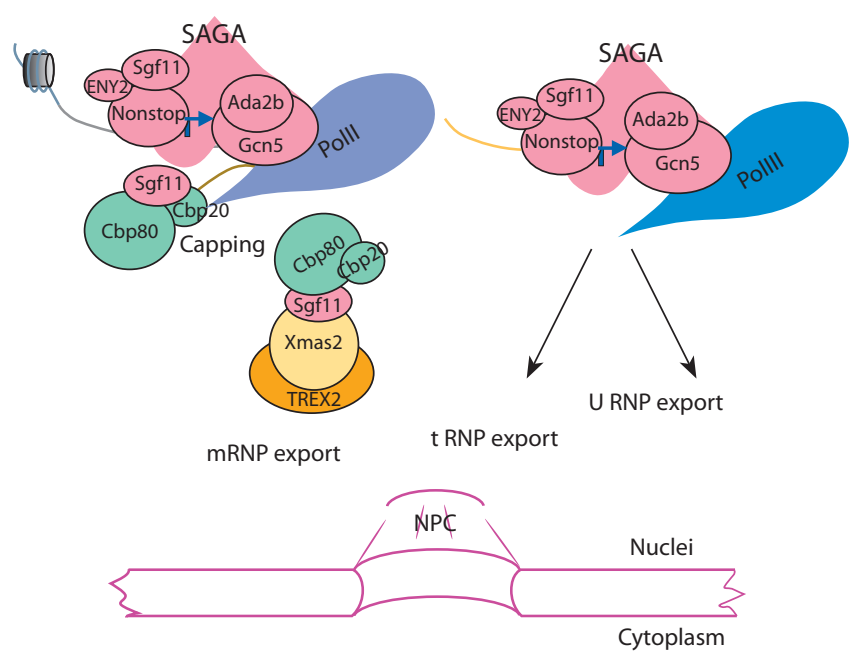

Fig. 7. SAGA proteins participate in the expression of both RNA Polll- and RNA Pollll-dependent genes.

The SAGA complex coactivates transcription from the promoters regulated by both RNA Polll and RNA PollII. Following transcription activation of RNA Polll-dependent genes, Sgf11 subunit of SAGA interacts with Cbp80 protein of the $\mathrm{CBC}$ complex and associates with growing mRNA. Sgf11 associates with mRNP, interacts with TREX-2/AMEX and is essential for mRNA export through the NPC.

phila pupae). This is in line with our results obtained for snRNA genes in the S2 cells. So, SAGA also takes part in snRNA gene regulation at the level of the whole organism.

For our genetic crosses we used mutant strains which carried mutations in genes encoding subunits of the DUB module (Sgf11 and Nonstop) and the HAT module (Gcn5 and Ada 2b). Each mutation was lethal in homozygotes because there was no test protein in the mutant line. Thus, we performed our experiments on heterozygous strains. In all strains, the level of investigated gene expression was decreased. The $T M 6 ; T B^{1 /+}$ heterozygotes were used as a control.

Using qRT-PCR we compared the $\operatorname{snRNA}(U 1$ and $U 6)$ transcription level in the mutant flies with that in the control strain. We also measured the transcription levels of two other PolIII dependent genes ( $t R N A$ Lys and 7SK). Our results showed that the mutations in all tested SAGA subunit genes caused significant decrease in the $U 1$ and $U 6 \operatorname{snRNA}$ transcription levels and had a weaker effect on $U 1$ snRNA transcription. Thus, the results confirmed that SAGA is indeed the coactivator of the transcription of snRNAs, as well as of PolIII-dependent genes. Decreased transcription levels were also observed for the $t R N A L y s$ and $7 S K$ genes.

It is important to indicate that mutations in SAGA subunits affected the attachment of Brfl to promoters of $U 6$ genes. The high level of Brfl detected on U6 promoters was significantly decreased in the fly strains with mutations. Thus, the SAGA complex may also be participating in the recruitment of PolIII transcription factors.

We addressed the question as to whether the level of $\mathrm{H} 2 \mathrm{~B}$ monoubiquitylation could also be influenced by SAGA mutations. For our investigation, we choose H2B monoubiquitylation of U6 96Ac, since, as had been shown previously, this gene was transcribed more actively than the other studied genes and we could better estimate the effect of mutation on
H2B monoubiquitylation. The antibodies against nonmodified $\mathrm{H} 2 \mathrm{~B}$ and against monoubiquitylated H2B (H2BK120Ub) were used. The data represent the ratio of $\mathrm{H} 2 \mathrm{BK} 120 \mathrm{Ub}$ to nonmodified $\mathrm{H} 2 \mathrm{~B}$, verified by $\mathrm{ChIP}$ in the control and mutant strains. The results obtained demonstrated that $\mathrm{H} 2 \mathrm{~B}$ monoubiquitylation increased in all mutated flies comparatively to the control.

\section{Conclusion}

Recently, X. Li et al. (2017) investigating SAGA-independent properties of the DUB module, detected by a ChIP-seq assay an occupancy of snRNA promoter regions by Sgf11, Spt3, and $A d a 2 b$ subunits. Our results are in agreement with the data that the DUB module has both SAGA-related and independent functions. In summary, it can be argued that the SAGA complex in metazoans is widely involved in the regulation of gene transcription (Popova et al., 2018).

Our model suggests that the SAGA complex is involved both in PolII and PolIII transcription, while some subunits of the complex participate in subsequent transcription steps (Fig. 7).

\section{References}

Baillat D., Gardini A., Cesaroni M., Shiekhattar R. Requirement for SNAPC1 in transcriptional responsiveness to diverse extracellular signals. Mol. Cell. Biol. 2012;32(22):4642-4650. DOI 10.1128/mcb. 00906-12.

Daniel J.A., Torok M.S., Sun Z.W., Schieltz D., Allis C.D., Yates J.R., Grant P.A. Deubiquitination of histone H2B by a yeast acetyltransferase complex regulates transcription. J. Biol. Chem. 2004;279(3): 1867-1871. DOI 10.1074/jbc.C300494200.

Georgieva S., Nabirochkina E., Dilworth F.J., Eickhoff H., Becker P., Tora L., Georgiev P., Soldatov A. The novel transcription factor e(y) 2 interacts with TAF(II) 40 and potentiates transcription activation on chromatin templates. Mol. Cell. Biol. 2001;21(15):52235231. DOI 10.1128/mcb.21.15.5223-5231.2001.

Gurskiy D., Orlova A., Vorobyeva N., Nabirochkina E., Krasnov A., Shidlovskii Y., Georgieva S., Kopytova D. The DUBm subunit Sgf11 is required for mRNA export and interacts with Cbp80 in Drosophila. Nucleic Acids Res. 2012;40(21):10689-10700. DOI 10.1093/nar/gks857.

Henry K.W., Wyce A., Lo W.S., Duggan L.J., Emre N.C., Kao C.F., Pillus L., Shilatifard A., Osley M.A., Berger S.L. Transcriptional activation via sequential histone $\mathrm{H} 2 \mathrm{~B}$ ubiquitylation and deubiquitylation, mediated by SAGA-associated Ubp8. Genes Dev. 2003; 17(21):2648-2663. DOI 10.1101/gad.1144003.

Kohler A., Pascual-Garcia P., Llopis A., Zapater M., Posas F., Hurt E., Rodriguez-Navarro S. The mRNA export factor Sus1 is involved in Spt/Ada/Gen5 acetyltransferase-mediated H2B deubiquitinylation through its interaction with Ubp8 and Sgf11. Mol. Biol. Cell. 2006;17(10):4228-4236. DOI 10.1091/mbc.e06-02-0098.

Kopytova D.V., Orlova A.V., Krasnov A.N., Gurskiy D.Y., Nikolenko J.V., Nabirochkina E.N., Shidlovskii Y.V., Georgieva S.G. Multifunctional factor ENY2 is associated with the THO complex and promotes its recruitment onto nascent mRNA. Genes Dev. 2010; 24(1):86-96. DOI 10.1101/gad.550010.

Kurshakova M.M., Krasnov A.N., Kopytova D.V., Shidlovskii Y.V., Nikolenko J.V., Nabirochkina E.N., Spehner D., Schultz P., Tora L., Georgieva S.G. SAGA and a novel Drosophila export complex anchor efficient transcription and mRNA export to NPC. EMBO J. 2007;26(24):4956-4965. DOI 10.1038/sj.emboj.7601901.

Lebedeva L.A., Nabirochkina E.N., Kurshakova M.M., Robert F., Krasnov A.N., Evgen'ev M.B., Kadonaga J.T., Georgieva S.G., Tora L. Occupancy of the Drosophila hsp70 promoter by a subset 
of basal transcription factors diminishes upon transcriptional activation. Proc. Natl. Acad. Sci. USA. 2005;102(50):18087-18092. DOI 10.1073/pnas.0509063102.

Lee K.K., Florens L., Swanson S.K., Washburn M.P., Workman J.L. The deubiquitylation activity of Ubp8 is dependent upon Sgf11 and its association with the SAGA complex. Mol. Cell. Biol. 2005; 25(3):1173-1182. DOI 10.1128/mcb.25.3.1173-1182.2005.

Li B., Carey M., Workman J.L. The role of chromatin during transcription. Cell. 2007;128(4):707-719. DOI 10.1016/j.cell.2007.01.015.

Li X., Seidel C.W., Szerszen L.T., Lange J.J., Workman J.L., Abmayr S.M. Enzymatic modules of the SAGA chromatin-modifying complex play distinct roles in Drosophila gene expression and development. Genes Dev. 2017;31(15):1588-1600. DOI 10.1101/gad. 300988.117.

Martinez E. Multi-protein complexes in eukaryotic gene transcription. Plant Mol. Biol. 2002;50(6):925-947.

Nagy Z., Tora L. Distinct GCN5/PCAF-containing complexes function as co-activators and are involved in transcription factor and global histone acetylation. Oncogene. 2007;26(37):5341-5357. DOI 10.1038/sj.onc. 1210604.

Nakamura Y., Tagawa K., Oka T., Sasabe T., Ito H., Shiwaku H., La Spada A.R., Okazawa H. Ataxin-7 associates with microtubules and stabilizes the cytoskeletal network. Hum. Mol. Genet. 2012; 21(5):1099-1110. DOI 10.1093/hmg/ddr539.

Popova V.V., Orlova A.V., Kurshakova M.M., Nikolenko J.V., Nabirochkina E.N., Georgieva S.G., Kopytova D.V. The role of SAGA coactivator complex in snRNA transcription. Cell Cycle. 2018; 17(15):1859-1870. DOI 10.1080/15384101.2018.1489175.
Powell D.W., Weaver C.M., Jennings J.L., McAfee K.J., He Y., Weil P.A., Link A.J. Cluster analysis of mass spectrometry data reveals a novel component of SAGA. Mol. Cell. Biol. 2004;24(16):7249-7259. DOI 10.1128/mcb.24.16.7249-7259.2004.

Rodriguez-Navarro S., Fischer T., Luo M.J., Antunez O., Brettschneider S., Lechner J., Perez-Ortin J.E., Reed R., Hurt E. Sus1, a functional component of the SAGA histone acetylase complex and the nuclear pore-associated mRNA export machinery. Cell. 2004;116(1): 75-86.

Weake V.M., Lee K.K., Guelman S., Lin C.H., Seidel C., Abmayr S.M., Workman J.L. SAGA-mediated H2B deubiquitination controls the development of neuronal connectivity in the Drosophila visual system. EMBO J. 2008;27(2):394-405. DOI 10.1038/sj.emboj.7601966.

Weake V.M., Swanson S.K., Mushegian A., Florens L., Washburn M.P., Abmayr S.M., Workman J.L. A novel histone fold domain-containing protein that replaces TAF6 in Drosophila SAGA is required for SAGA-dependent gene expression. Genes Dev. 2009;23(24):28182823. DOI $10.1101 /$ gad.1846409.

Wu P.Y., Ruhlmann C., Winston F., Schultz P. Molecular architecture of the S. cerevisiae SAGA complex. Mol. Cell. 2004;15(2):199-208. DOI 10.1016/j.molcel.2004.06.005.

Zhao Y., Lang G., Ito S., Bonnet J., Metzger E., Sawatsubashi S., Suzuki E., Le Guezennec X., Stunnenberg H.G., Krasnov A., Georgieva S.G., Schule R., Takeyama K., Kato S., Tora L., Devys D. A TFTC/STAGA module mediates histone $\mathrm{H} 2 \mathrm{~A}$ and $\mathrm{H} 2 \mathrm{~B}$ deubiquitination, coactivates nuclear receptors, and counteracts heterochromatin silencing. Mol. Cell. 2008;29(1):92-101. DOI 10.1016/j. molcel.2007.12.011.

\section{ORCID ID}

E.N. Nabirochkina orcid.org/0000-0002-7942-3924

M.M. Kurshakova orcid.org/0000-0001-6772-6955

S.G. Georgieva orcid.org/0000-0003-3665-0390

D.V. Kopytova orcid.org/0000-0003-1086-6329

Acknowledgements. This study was supported by the grant RFBR No. 18-04-00514 (Kopytova D.V., Nabirochkina E.N.). Conflict of interest. The authors declare no conflict of interest.

Received November 22, 2018. Revised December 13, 2018. Accepted December 13, 2018. 